井本英一

文化には，その現象はさまざまな形をとっていても，その本質は同じ であると考光られるものがある。以下に述べることは，すべてこの観点 飞立つ。ここでは，数千年のときの流れは無視するので，歴史性は，い

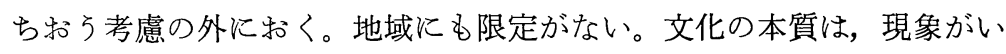
か腹合し，多様性をもってもかわることがないと自分は考光るからで ある。

一地域の文化を解釈するばあい，その地域の文化のみを対象とする と，その文化圈の人間洔特有な思考過程をへた解釈に到達はする。ここ では，歴史時代の人間の合理的，ひいては現代人の便宜的な解积が支配 しがちである。ことなった地域の文化が，同じ本質の上に立っていると 直観的考光られても，それぞれ起源をことにして語り伝觉られている のがこれである。ここでは，本質を解釈しないで，現象をあらたに本質 として解积しているのである。

自分がい打らとする本質は，1個の果実の種子のように，これがそ5 だとはっきり指摘できるものではない。個々の現象から析出した漠然と した共通像である。対象とする現象が多いほど，本質らしい像は上り明 瞭に浮び上ってくる。この像を得るには，此較は不可欠な手段である。 比較の範囲を, 等質的な, あるいは相互関倸的な文化圈内だけで行なって も, ある程度の目的は達せられる。しかし，冒頭に述べた仮説にもとづ いて，比較の範囲をまったく限定しないとき，到達する像はおのずとこ となったものとなってくる。結論侸するためには, 思いきって論理を 飛躍させ，前論理の世界にはいらなければならないと考穴る。 
こうして得られた共通像のすべてが，個々の現象に投影されていない のがふつろである。あるいは，ときの流れとともに，この投影が曇って しまったといった方が適切かもしれない。研究者の知識の欠如から，投 影をみのがすばあいも多いと考学られる。いずれにしても，個々の現象 が相い補って，ある共通像ないしは全体像をつくり上げていると自分は 考えている。

本質らしい共通像が得られたとき，文化事象の解釈は，従来のそれと は別のものとなってしまう。現象的には，まったく無関係だと思われる ものも，共通像を得ることによって相互関係が浮び上ってくる。

本質は, 比較言語学でいう祖語のようなものだと考光ればよい。祖語 は実在しないが，同系の言語群から析出された共通像であることにはか わりがない。たとえば，印欧語では「5」の祖型は* ${ }^{*}$ penk $k^{\mathrm{u} e} e$ であって， 他の系統のことばによって代替されないかぎり，いつまでたっても，そ れは不変である。印欧語族では, 祖語の話されていた故地が考兄られて いる。A. Meillet は, 印欧語とウラル語, 印欧語とセム語のあいだに, 太古には密接な関係があったと考光ているが，もし，3つの語族が太古 に関係があったと仮定するならば，その祖語の故地は，もはや求めるべ くもない。きわめて歴史の浅い言語にして，このありさまである。言語 以外の文化事象について考察するとき，かりに本質らしいものをつか及 えても，その発生源をつきとめることは不可能といってょい。考古学的 あるいは文献的初出によって，発生地と考光るのは不可である。

言語以外の文化事象の比較を行なうばあい，言語の語族関係とはきり はなして行なわなければならない。

歴史時代のオリエントと東亜飞打いては，言語の親属関係は証明され ない。かりに，太古に，関係があったと仮定しても，祖型までたどりつ く作業は不可能といってよい。しかし，言語以外の文化事象では，比較 によってその本質にたどりつくことができるものがある。世界，ことに 
旧大陸の各地に散らばっている文化の剩余のなかに，求めようとする本 質がひそんでいると考㝋られるオリエント研究者にとって，東亜の文 化的剰余も，比較の立場にたつかぎり不可欠なものである。日本人にと っては，入手しやすい日本文化の剩余と比較することがはや道である。 このばあい，文化事象相互にみられる差異は，念頭に置かないで，もっ ぱら本質らしいものを求めるよ5にする。求め光た本質らしいものか ら，逆に，東亚ないし日本の文化をみようと考光る。

人間はある発展段階に達すると, 共通した文化態様に到達することが ある。これとは別に, 人間には, 旧石器時代以来の遺産で, 太古から文 化交流して複合した文化があると考えなければ，解釈のできない現象が 多々ある。

隣接した文化圏に，同時期あるいは連続した時期に，本質は同じで， 現象的にも類似した文化事象がみられるばあい，一方から他方への文化 的影響と解釈するのがふつうである。また，ことなった近接地域に，か なりの年月をへだてて，類似の事象がみられるときに，それを以前の文 化の直接の遺産であるかのように説明するのもふつうである。もちろ ん，確実なばあいも多い。ところが，隔絶した地域に，本質を同じくす ると考光られる事象がみられるばあい，どう説明したらよいのかわから なくなってしまう。3つのばあいとも，文化接触と解釈するほかに，太 古からの遺産の個々のあらわれと解釈するほうが便利なことがある。

ユダヤ教に対するイラン文化の影響が，バビロンの幽囚いらい顕著に なったことは, 広く認められるところである (cf. R. Otto, Reich Gottes und Menschensohn, 1934)。しかし, dualism を例にとってみると, dualism が イランのゾロアストラ教的思想の創造であり，イスラェル以外の文化圏 にはみられないものであるなら, 歴史的な証拠はなくても,イラニズムの イスラエルへの影響とみなすこともできよう。ところが， dualism の萠 
芽は括々らく中期旧石器時代にみられるるので，そのあらわれはオリエ ントの新石器時代から，ずっとくだって極東にまでみられるものであ る(拙稿「2 とは何か」西南アジア研究 No. 13, 1964 を参照)。ユダヤの 2 元論 も，イランの 2 元論も，太古からの陰陽闘争の思想が，それぞれの民 族によって体系化されたものとも考光られるのである。P. Schmidt, Persian Dualism in the FarEast, in Oriental Studies in honour of C. E. Pavry, 1933, pp. 405-6 は, 中国の陰陽思想が，イランの 2 元論の影響 をうけたと考兄れるとし，その chronology を孔子以後として，シナ 語「陰」の古音はイランの Yima であるとするが，自分はとらない。

終末観についてはな拈さらである。不死の思想はオリェント全般に あった。黄泉の世界は多く民族が有するものである。審判と善悪の記帳 はェジプトにもゾ教にも仏教にもある。復活もそうである。救世主に関 しては, イランのサオシャントよりは，ユダヤのメシャと仏教の仏のほ らが近いのである。後者ではいずれも，己れを犠牲にして，自分自身が 救われ，人類を救うからである。イランでは，ずっとのちのマニ教にこ の思想があらわれてくる。

精霊とい5概念は，ギリシア語訳にはじをるが，旧約時代のそれは， サムソンに乗りらつったよらな巨大な，異常な力であったと考觉られ る。イランの Spənta Mainyu は Holy Spirit に対比される概念である が，これは，最初から “恩竉のある霊”として考えられていたかどうか， 自分は疑いをもっている。

10〜11世紀にいたっても，アヴェスタ語 spanta は，パフラヴィー語， サンスクリット語では, ‘増長, 増大’ と注釈されているのである (Pahl. $a \beta z \bar{o} \bar{\imath} k$, Skt. vrddhih)。神は無際限なものと考兄られていたらしい。イ ランのズルヴァンがそうである。仏教の無量寿仏や無量光仏もこれと関 係がある。別稿「2 とは何か」で，ヘロドトスの記述するオリェントの 巨大な 1 対の人像や，日本のネブタについて，その巨大さの理由を保留 
しておいたが，巨大な仏像などをこめて，この世からあの世へはいると き，巨大になるらしいことがわかる。

巨人は世界のどの民族でも，天地創造に関与している。琉球のアマン チュウ（天の人）は両腕で天を支えて大地に立っている（ギリシアのアト ラスが，極西の国で同じことをしている)。イザナギ，イザナミ神の神話も， 国引きの神話も，巨人でなければできないものである。イラン神話で も，アフラマズダーやガヨーマルトは，巨大なものであったと推論しな ければならない。古代文明の栄えた多くの地域で，神殿や陵墓が実に巨 大な構築物であるのは，政治的，経済的な背景とならんで，神や地上の 王は巨大なものであるという信仰があったからかも知れない。

これに反して，あの世からこの世にくるばあい，あるいは人間があの 世からこの世に復活するときは，小さな形をとったらしい。

アフラマズダーが世界を創造するには，巨大な異常な力つまりスプン タ・マンユが必要であった。それは，H. Humbach の 'heilvolles Streben' の解釈や，それ以前の解勫では理解できないのである。やや後期からあ らわれる Aməša Spənta も, “恩龍ある不死者’というょりは, 上に述べ た異常な力をもった不死者でなければならない。スンタ・マプンユに対 立する概念 Angra Mainyu は，“悪の努力’，“破壊的な努力’ではないの である。Yasna 45.2 にあるように, この世には2つの原初的なマンニ つまりタマシイ (cf. Ved. manyú-) がある。これを混同してしまうのは, 生命のためによくないのである。

スプンタ・マンュは, ゾロアストラ, 釈迦, イェス・キリスト, マホ メットにつぎつぎとあらわれたものであり，日本ではアラヒト神にあら われるものである。のちには一般の人間にもあらわれたが，はじめは， 現世の絶対者や王にあらわれたものであった。この解积に到達するため には，オリエントから日本へかけての例を求めなければならない。 イランでは，スプンタとアンラの 2 つの対立するタマシイがあったの 
は，上述したとおりである。後期のアヴェスタに出てくる fravaši は， パフラヴィー語の伝承では，創造者アフラマズダーの前にあるものとさ れ (Gr Bd. p. 34), 年末の 5 日間, 人間の fravahr (フラワシのパ語形) が 群をなして降りてくるとされる(Gr Bd. p. 24)。

上の 2 つ記録から，つぎのことが推論される。フラワシは創造主の がわにあるタマシイで，年末つまり大晦日にやってくるということは， 通過に特けるつぎの生の創造を行ならためにやってくるということであ る。フラワシを陽,生の力とすれば,院, 死の力があったはずである。それ はアンラ・マンユしかない。アヴェスタでは, すでに Yašt 13.49 以下 で，祖霊崇拝がフラワシ信仰と習合してしまっている。現在，ゾ教徒が 新年に迎光る frōhar（フラワシのペルシア語形）は，祖先の霊としか考光 られていないのである。

わが国で，年に 2 回，すなわち新年と中元，あるいは春秋の彼岸に祖 霊を迎方る行事があるが，これは単に祖霊のみをまつるものではなかっ た。生き盆に，両親あるいは年長者に食物を供して，その生命力を更 新, 増長させようとする古い慣習が地方に残っているからである。

そこで，タマ祭りの本質は，祖先の霊をまつることではなく，賦活力 のあるタマシイの祭りであったと自分は考光る。それは，人間生活の折 り目にあたって，古い穀から脱して新しい生命力をえんとした行事であ った。ウラボンの行事も，フラワシをまつる行事が，祖先のタマ祭りと 考えられるようになったのである（拙稿 OldIranian ortăvan-, インド学試論 集 No. 6, 1965 を参照)。

フラワシは，そこで，スプンタと同じはんちゅうの概念であった。フ ラワシを迎えるのに，ドラをたたき，爆竹をならし，火をたくのは，祖 霊を迎えるしめっぽい行事ではなかったわけである。

Av. fravaši- の語源について, H. W. Bailey, Zoroastrian Problems in the Ninth-Century Books, 1943, p. 109 は, -vaši-, -vart-を Pahl., Pers. 
gurt, gurd “英雄” にかけている。ところが, Iran. rt, art は urt, urd になるが, Iran. art (=Av. aš) はそ5はならない（cf. Pahl. art, ahr)。 Yašt 13.53 以下では，フラワシが，世界のはじめにおいて，流れなか った水，成長しなかった樹，運行しなかった星辰を活動せしめるのであ る。フラワシは，ここでは祖霊とは関係ないものである。サンスクリッ ト語注のよ5に，やはり増大，促進（者）と自分は考えたい。 Av. spanta-も，語源的には “増大’の意味をもつものと自分は考えたが (拙稿, Videvdat 8.1-19 の注解, 広島大学文学部紀要第 22 巻 3 号を参照), こ れに対するアンラ・マンユは, 前者の動に対して, 静の概念をしめし, ゾ教教義では悪に発展したものと考える。

エジプトには ka と ba の代表的なタマシイがあった。エジプト学で は, 人間が死ぬと, 人間に内在する ba は鳥の姿となって（日本武尊のなき がらから飛びたった鳥は、エジプトふうにいえば ba にあたる)天国あるいは地 下の国へゆき，ka のもとにいたる。 $\mathrm{ka}$ は肉体には内在しない，独立し た存在であった。 $\mathrm{ka}$ はことに王者に帰属し，創造的な生命力をもった 存在であったが，のちには庶民にも関係するようになり，生命の原理と しての地位を觉るよになった。 ka が両腕をあげた形で象徵されるの に対して，ba は人頭鳥身の奇怪な姿で象徵された。 $\mathrm{ka}$ は守護神として も考えられていたようである。エジプト学では, ka と ba とは截然と 区別しえないようである。

イラニストにとっては，スプンタとフラワシが，エジプトの ka に相 当することが明らかになるだろう。イランのアンラ・マンユは陰のタマ シイに属するエジプトの ba に相当すると考它なければならない。ガー サーにはフラワシは出てこないが, Yasna 45.5 その他では, daēnāとurvan の 2 つタマシイが出てくる。ガーサーのいずれの個所でも， こ の 2 つタマシイは, 死からつぎの世界へ通過するさいにあらわれるこ とだけは共通している。たぶん， daēnā が陽のタマシイであった。 
印欧語には, ドイツ語の Mann と Mensch, ラテン語の vir と homo, サンスリット語の vīra と nro, イラン語の vīra と nar のように, 2 種類の人間のいいあらわしかたがあった。前者は, 男らしい人間, 英雄, 戦士を, 後者は, ふつらの人間をあらわす語であった。自分は以前に, 印欧語にはタマシイをあらわす語として,*an(ə)-のほかに*au- という 語根が存在したらしいことを推論した。鳥にも, Lat. avis, anas, Skt. vi-, atti-のように，ふたとおりのものがあったらしいが，人間のばあ いのよ5には，もとの意味ははっきりとあらわれていない。いずれにし ても, *au-は陽の, *an(ə)- は陰のタマシイをあらわしている。Skt. avasは, ‘神のたすけ’つまりあの世からの賦活的な力をあらわす語である。

新約では，完全なる人間性は，肉体と精神と霊魂とから成っていると 述べられている（テサロニケ前書 5.23；コリント前書 15.44 , 46; ヘブル書 4 . 12 を参照)。これは, 旧約さらにはセム人の RWH と NFS にまでさか のぼるものと考光なければならないが，新約のいみするところでは，霊 魂が陽で精神が陰であったらしい。NFS は, イキつまり息, 生きであ って，陰に属したものではないかと思う。

中国人は，陽に属するタマシイを魂，陰に属するそれを魄と称してい た。人間の肉体に直接関係のあるのは後者のタマシイであって，それは エジプト人の ba と同じょうに, 死後は肉体から遊離した。魂は気で, 天からうけたものであり，魄は形で，地に帰するものであるが，ともに 不死のものと考えていた。そこで，中国人の考えでは，祖先をまつるこ とは，祖先の魂と魄とを天地から招くことにほかならなかったのであ る。

日本には，古くからアラミタマ(荒魂) とニキミタマ(和魂) の区別が あった。これはさらに, クシ（奇）ミタマとサキ（幸）ミタマとしても考 えられていたようである。江戸時代の国学者は，消極的にではあるが， 1 神 2 魂説という思想にたどりつき，説明に窮していたようである。国 
学者の推論は妥当であったと思う。日本人は当初から外来魂と内在魂 の観念をもっていた。例の大国主命と少彦名命の物語りでは，大国主の 外来魂である少彦名が，常世の国から訪れてくるのである。それがクシ 神と呼ばれているからには，クシミタマの化身であったことが5かがえ るのである。これは，エジプト人の $\mathrm{ka}$ の像に相当するもので，イラン のパサルガダエにあるいわゆるキュロス像も，結局は本質的には同じも のなのだと思う。世界の多くの地域で，人間の撮影をタブーとするが， 写真像を ka の像と考光て，それを他人に支配されるのをいみきらうの か，ba が人体から拔け出して，写真像に移るためか，いずれかであろ う。同じょうに，多くの地域で行なわれる人形呪いは，類感呪術とし て，その本人への analogy として行なわれるのか，あるいは，人形こそ ka の像で，これを迫害して，人間を弱らせるのか，どちらかであろう。 いずれも，ka の像の世界的な résidu と自分は考皇たい。

古代の日本人も，他の民族と同じょうに，多くのタマシイの存在を信 じていたが，本質的には上に述べた 1 対のタマシイが基調なをしていた と自分は考える。つまり，なま身の肉体には和魂あるいは幸魂が宿って いたが，もうひとつのタマシイである荒魂または奇魂は，と拈い常世の 国にあり，それが，ときにふれてやってくるものと考光ていたらしい。 つまり，まれびとである。荒魂をまつることは，そこで，このタマシイ のもつ生命力，異力をわが身に呼び寄せようとするものだったと考兄ら れる。

荒魂は，本質的にはエジプト人の $\mathrm{ka}$ ，イランのスプンタ・マンユあ るいはフラワシにあたるもので, 生命の源泉, 創造の原動力と考觉られ ていたと考劣なければならない。古代日本人が，ムスビ（産霊）と称し ていたものは, この奇魂のことであり, 文字どおり生産力のある霊であ った。荒魂は，ka やフラワシがそうであるように，守護霊としても崇 ばれ，国家鎮護のためにも祈願された。らつせみの肉体に，この荒魂を 
そなえた者は，アラヒトで，ヒト（霊人）とは全くことなっていた。ク シビ (奇霊), ムスビの所有者は, 天皇であらせられ, エジプトふらにいえ ば，ファラオであったわけである。美術では，メンカウラ王の像によく あらわれている。

新嘗祭の前日に行なわれる鎮魂祭は，民俗学の解釈を別にして，単 に，肉体から遊離しようとする魂を呼びもどす呪術でもなく，単なるた ましずめの行事でもなかったと自分は考える。アラヒトであらせられる 天皇が，毎年，荒魂である新しい穀霊をとられて，よみがえられる通過 儀礼において，新しい荒魂を呼び寄せ，それを身につけられる祭りであ ったと解釈しなければならない。通過は，夕の儀と暁の儀をへて完了す るのである。

さかし宮中で，6月と12月の晦日に行なわれた節折（ヨオリ）の儀で は，天皇，皇后，東宮の等身大の竹（御丈に通じるのか）それぞれ 2 本が 用意された。アラヨとニコヨの 2 本の竹に，災厄をらつす笼いの行事と されているが，自分は逆に，この形代から，神人が新しい賦活力をえら れたのが原型だと考える。 $\mathrm{ka}$ の像にあたるアラヨだけでなく，ba の像 にあたるニコヨも用意されたのは，通過儀礼に特いて，この 2 つが必要 とされたからであると思う。天皇, 皇后, 東宮は, この 2 つものの超 越者となられるためであった。

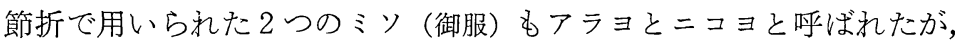
前者が霊能を有したと考えなければならない。ペルシア文学にしばしば あらわれる恩賜の衣は，同時に経カタビラでもあった。 $\mathrm{ka}$ に相当する 霊力は，生者のみでなく，復活せんとする死者にも不可欠のものであっ た。鎮魂祭の御衣もこれなのである。

エジプトやイランの王，あるいは世界の多くの王が，新年に臣下に与 えた恩物は，あらたま，つまり年玉であって神人としての王が，人間に 賜わるものであったと自分は考光る。それは，いろいろな形で発展して 
いる。これも庶民に及んだ。

年に 2 度もなぜ笼いを行なわなければならないのか。春に穀霊をむか え，秋にそれを送る行事のなごりか，あるいは，暦の関係で，春秋，冬 夏新年のなごりがそれなのか，明らかではない。イランの fravartīn そ mihragān, 日本の新年と中元のタマ祭り，仏教の春秋の彼岸会には，祖 先崇捀と習合してしまったけれぞも，このなごりがみられる。

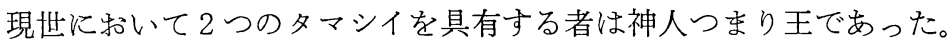
それは，のちに庶民にまで及ぶようになった。さらに，陽陰のタマシイ に価值観が生ずるようになったと考穴れる。生死，善悪，男女，右左 などの対立概念である。

上に述べたように，ェジプト人は自分の Doppelgänger である ka の 像の存在を信じていた。ミイラを覆う棺である等身大の像も $\mathrm{ka}$ の像と 呼ばれたが，エジプト学で代用像と称するのは，現象的な機能面からみ ての名称であろう。ミイラは ka の像とともにひとつの全体をなし， 像は ka の部屋で儀礼をうけた。ba がいち抢う飛びたったミイラにし ても, ka の像と対置されるときは, 当然, ba の宿るべき場所であっ た。エジプト人にとっては，復活するのはあくまで ba の宿る肉体で， $\mathrm{ka}$ の像ではなかった。 $\mathrm{ka}$ の像が，ミイラが崩壊したのちも，生きのこ るため, ka の像を不死者とするとは，自分は考えない。

口を開く儀式が $\mathrm{ka}$ の像に対して行なわれた。それは，kaの像の吐 く息に宿る ka を，ミイラに呼び寄せようとする呪術ではなかったかと 思う。ミイラの代用として, 日々の食物を供したのは, 発展した形であ ると考觉られる。死の象徴としての開口でもなかったようである。 エジプト美術で，死せるオシリスに，聖職者が，crux ansataをつけ た壸から聖水をかけて，麦の発芽を促がす，すなわちオシリスを復活さ せるのがある。あとで述べるように，十字はひと形，つまり $\mathrm{ka}$ の像の 象徵と自分は考光るので, 聖水は ka そのものであったのである。 
別の美術では，死せるオシリスはホルスの眼を刻まれて復活するので ある。これは，仏教の開眼を思わせるものである。仏像に霊をいれるた めには，この儀式が必要であった。ホルスの眼や，仏像の眼からみて， ba の像が，kaをうケいれるためには，眼を開かなければならなかった のだろらか。ホルスの眼は，ka すなわちアラミタマそのものであった のかも知れない。のちに太陽崇拝と習合して ra と考觉られるようにな ったのではないかと思う。有翼円盤として王者の頭上に浮游するのは， $\mathrm{ka}$ とみなければならないのである。オリエント全域にみられるこの変 形も，そ弓解釈したい。nimbus すなわち光背は，さらにこの変形では ないかと自分は思う。超越者のもつ ka をあらわしたものなのだろう。 神武天皇の金铇も, もちろん, 天皇の $\mathrm{ka}$ が飛来したと解釈する。自分 は太陽とは関係づけない。ひとつ目小僧も，このような手続きで考学る と，ka の像だったことになる。片目の魚の神聖なわけも，そうだと考 える。ダリウス 1 世が, 敵将の片目をつぶして, 宮門にさらしたのも, 敵将の kaを自分のものとせんためであったと思う。

Khabur 河流域の Tell Brak で，Mallowan 教授が発堀した土偶は， Eye goddess と呼ばれ，3 重の同心円形の眼をもっている。これらの女 神像は穀霊である地母神像にちがいないので，これらの眼は銡霊の復活 を願ってつけられたものと思う。

北九州の装飾古墳にみられる 3 重の同心円は，朱色の面に絵かれてい るので，とうぜん復活が意図されたと思う。この同心円は，括とらく太 陽崇拝とは関係なく，上に述べたホルスの眼，すなわちアラミタマと関 係があるものと自分は考劣る。これは，のちに述べる螺旋とも密接な関 係をもつもので，いずれも死者にとっては不可欠な外来魂であったと思 われる。

神社では，大晦日に，氏子に配っておいたひと形をあつめて，川に流 す。神道では，1年間の罪，けがれをこの形代に移して，新しい年を迎 
えるというのである。上来の自分の仮説によると，これでは説明がつか なくなる。自分の考光では，形代といわれるものは，本質的にはエジプ ト人の $\mathrm{ka}$ の像と全く同じもので，としのかわり目に，新しい生命力を 賦与するため，常世の国からやって来た荒魂の像なのである。これで体 をなでるのは，なま身を賦活するためであって，罪，けがれを移すとい うのは本質的なものではない。川に流すのも，笼いではなく，荒魂の像 を常世の国に送りかえすためだと思う。ネブタにしても，ひな人形にし ても，本質は同じである。ここで，形代の形象に注目しよう。それは， 丁字あるいは十字に近い。

仮の王に選ばれるものは，何らかの霊能の保持者とみなされる異常者 であったはずである。真の王にとっては，かれから，その霊能をうけと ることは切実な問題であった。

キリスト教では，十字架はイエス・キリストの苦難と，自己犠牲の愛 の象徴であるとし, 十字架を本来は刑罰の器具と解釈する向きもある。 キリスト教徒の墓に,十字がともならのは,キリストの愛の救済にあずか ろうというわけである。ところが，十字と墓との結びつきは，アケメネ ス王墓にあらわれるのみでなく，殷墟の亜字形墓にもみられるのである。

いっぽラ，エジプトでは，ややことなった十字 crux ansata は，死 せるオシリスの復活には不可欠なものであった。上述したようにオン リスの肉体から浪，麦が成長してゆくのである。

エーゲ文明やヒッタイト文明では，女神や王は，右手に double-axe を もつ。この使用不明の, 扢そらくは祭儀に用いらた道具も, 抢そらく十 字の変形ではないかと思 弓。人類の文化史上もっとも重要な道具のひと つである斧は，通過儀礼に用いられたものと自分は考光る。

仏教では，マンジ（付）は，吉祥のしるしとして，仏像の胸などにし るされている。それは墓や死とは，いちおうへだたっているようにみ充 る。慧琳の一切経音義には, 万字 (çrivatsa) とともに, 十字 (svastika) 
が出てくる。後述するように，万字は十字の変形である。

十字や万字は, 前 3000 年の北欧新石器時代の土器にも刻をれている。 ヨーロッパでは，これは 4 つ輻の車輪あるいは太陽（の回転），すなわ ち生命力と解されているが，自分の解釈はちがっている。このしるし は, ヨーロッパの多くの先史遺物に残っている。

新大陸では, 前インカの遺物のなかに, 万字の変形とみられるものが ある。ただ，その交叉部には，顔が描かれているので，いかにも人間が 手足を躍動させているょうにみえる。これも太陽の象徵と解釈されてい る。

アイヌ人が，死体を埋葬したあと，その上に立てる墓標に，注目すべ きものがある。それは，丁字形，子供の遊びで用いるネッキそっくりな $\mathrm{Y}$ 字形，コケシ人形と同じ形，槍形あるいは，ロウソクに火をともした 形などで代表される。さらに，注目すべきことは，墓標の頭部にあたる 部分にダ円形の凹みをほり，ここに消し炭が塗られることである。これ は，火の神の使いが死者をあの世に案内するためと解釈されているが (藤本英夫, アイ邓の墓, 昭 39,38 頁)，上来の自分の解釈から推論すると，墓 標はエジプト人の $\mathrm{ka}$ の像と本質的には同一のものなのである。頭部の 凹久は，ka の像の開口と同じ意味を本来はもっていたはずである。つ まり, 墓標は $\mathrm{ka}$ の像であるので, 死者を復活させるために必要であっ たわけである。このようにみてくると，仏教のソトバも，原型は $\mathrm{ka} の$ 像であったかも知れないのである。埋葬地の目じるしとは考光られな い。京都の大文字山の送り火をみると，それは，祖先崇拝と習合した ka を，あの世に送りか觉す行事だと思わざるを觉ない。大文字は，ひと形 なのではないかと思う。

エジプトの crux ansata とアイヌの墓標, エジプトの ka の像と日本 の形代とを対置してみると，十字の本源はひと形であったことが明らか になろろ。アイヌ人のY字形墓標も人間の形象なのである。ネッキ遊び 
は，季節のかわり目になされた，2つのひと形の競技であったはずであ る。

アケメネス諸王も，殷王も，アイヌ人も日本人も，エジプト人の ka の像と本質的には同じものをともなって，新しい生にはいっていったの である。

亜は, ka の像であるとともに, 'another', 'second’ の意味をもったも のと自分は考学る。

キリスト教の十字と仏教の万字は, 本質的には同じものである。慧苑 音義第一の図と慧琳音義第二十一所収の慧苑音義所出の図は，ややこと なっているが, 万字 (çrivitsa), 螺旋 (nandyāvarta), 十字 (svastika), 壼 (pūrnaghata) の 4 つの吉祥のしるしを図示している。北欧の, 前2000 年紀後半の青銅器に, 万字のそれぞれのかぎが螺旋になったものがあ る。螺旋と同心円とは，増大すなわち $\mathrm{ka}$ の生命力の象徵化されたもの ではないかと思われる。本来は眼ではなかったわけである。死せるオシ リスや仏像に眼をいれることは，kaをいれることにほかならなかった ということになる。万字は, ひと形から十字へ形象化される途中の形 で, crux ansata もとの中間形であったと考光られる

殷周青銅器に刻まれたトウテッ紋（眼がついている）は，怪獣の図柄で はなく，自分は万字の変形だと思う。この青銅器とまったく類似した土 器がイランでも出土しているが(「2 とは何かっで触れた ), 後者には, いわ ゆるアンダーソンの啔紋がついている。両者とも, 自分は通過儀礼で用 いられた器具と思っているので, トウテッ紋も喪紋も, ka をあらわし ているのではないかと思っている。エジプトの聖職者が，死せるオシリ スに向って手にする, crux ansata のついた容器と結局は同じものにな るのである。もしそうだとすると，アンダーソンの襄紋はかれの解釈と はちがって, 万字の変形あるいは, ka の別様の形象と考光られること になる。 
最後に，一切経音義の螜についていえば，それは通過儀礼ではかなり 重要な役割をはたしていたらしい。これは, 時代的には土器が登場して からのことである。日本で, 結婚式, 葬式に和いて, 茶碗を割って，つ ぎの生へはいってゆくのは，本質をよくあらわしている。ェジプトの ka の䨌とは別に，オリェント全般にみられる，日本の合せロカメ棺と同じ pithoi，エーゲ文明にみられる $2 つ の$ pithoi一ひとつからは植物が芽 ばえ出しているが，からの pithos に対しては mater dolorosa がなげい ている—のよ5に，壶には陽陰 2 つのものがあったことがわかる。 つぎの生へはいるには，陽の冨から ka をもらう必要があった。日本 人が破棄する茶碗には，ka がはいっていると考光なければならない。 イラン人は新年の前夜, 屋根から道路に食器を投げて破革する。京都の 壬生寺でも季節のかわり目に同じようなことをする。

周知のように, アイヌ人は, 葬式の終了後, 桶を墓標につきさして, 底を抜いてし亡う。底なしの桶はオリェントにもみられる。Hagia Triada の墓室には, 地下に埋葬された死体のために, 底なし桶から牡牛の 血を地面にそそいでいる図がある (M. P. Nilsson, Minoan-Mycenaean Religion $^{2}, 1950$, pp. 428 ff.)。エジプト人の壶と聖水を連想させる。アイヌ人 の桶にも ka がはいっていて，その口を開けたわけである。

上例から，つぎのことが推論される。监ないし容器には, タマシイが 内在すると考号れていたこと，しかも，2 種類の䝂があったことであ る。破棄する螜の方には，エジプト人の ka がはいっていたと考兄られ る。そこで死者が墓室にたずさえるのは，ka のはいった壶であったと 考えられる。さらに空想をたくましくすれば, 死者が墓中に 1 対の容器 をたずさえるばあい，死体の両がわにそえる容器の右がわが，はじめか ら壞されていたかも知れない，といらことである。(昭和39年10月） 


\title{
The Near East and Japan
}

\author{
Eiichi Iмото
}

By comparison between cultures of the Near East and Japan, we see a essential part of both cultures.

In this way we see that the spanta mainyu of ancient Iran is the same as the $k a$ of ancient Egypt as well as the aramitama of ancient Japan and the cross is the same as the effigy which brings the $k a$ for mankind. 